\title{
136. Der Effekt der Hiatusschlitzeinengung und Fundopexie auf das untere oesophageale Verschlußsegment (L.E.S.)
}

\author{
Ch. F. Förster, T. R. Weihrauch und K.-D. Höhle \\ Chirurg. Univ.-Klinik Mainz
}

\section{The Effect of Hiatal Narrowing and Fundopexy on the Lower Esophageal Sphincter (L.E.S.)}

\begin{abstract}
Summary. In a prospective study the effect of hiatal narrowing with fundopexy on the function of the L.E.S. was studied in 15 patients. Pre- and postoperative clinical and radiographic symptoms, and results of esophageal manometry were compared. The L.E.S. resting pressure and pressure response on pentagastrin were recorded with a newly developed electronic IP-pressure transducer. Postoperatively only 2 of the 15 patients still had symptoms. Postoperative manometry revealed significantly increased resting pressures $(P>0.001)$ and an increase in the pentagastrin sensitivity of the L.E.S. $(P>0.005)$.
\end{abstract}

Key words: Sphincter pressure, lower esophageal sphincter - Manometry; transducer, IP pressure.

Zusammenfassung. Die Wirkung der Hiatuseinengung und Fundopexie auf den L.E.S. wurde in einer prospek tiven Studie untersucht. Prä- und postoperativ wurden klinische Symptomatik, die Ergebnisse der Röntgendiagnostik und die Oesophagusmanometrie verglichen. Die Druckmessung wurde mit einem neuartigen elektronischen IP-Druckaufnehmer vorgenommen. Postoperativ gaben nur noch 2 der 15 Patienten Beschwerden an. Röntgenologisch war keine Hernie mehr nachzuweisen. Die Ruhedrucke im L.E.S. waren postoperativ hoch signifikant erhöht $(P>0,001)$; seine Pentagastrinstimulierbarkeit zeigte signifikant höhere Werte $(P>0,005)$.

Schlïsselwörter: Elektronischer IP-Druckaufnehmer - Oesophagusmanometrie - Hiatusgleithernie - unterer Oesophagussphincter (L.E.S.).

\section{Funktionsgerechte chirurgische Therapie der Komplikationen des Endobrachyoesophagus (speziell peptische Oesophagusstenose)}

\author{
R. Siewert und H.-J. Peiper \\ Klinik und Poliklinik für Allgemeinchirurgie der Universität Göttingen
}

Functional Surgical Treatment of Complications of the Endobrachyesophagus (with Particular Reference to Peptic Esophageal Stenosis)

Summary. Endobrachyesophagus is generally an acquired metaplasia of the columnar epithelium of the distal esophagus. It is very rare in its congenital form. Apart from malignant degeneration and esophageal ulcer, peptic stenosis is the commonest complication. This can develop as a result of the 